\title{
Utilization of Coal Fly Ash as CO Gas Adsorbent
}

\author{
Dyah Sawitri $^{\# 1}$, Ayu Lasryza ${ }^{\# 2}$ \\ ${ }^{*}$ Department of Engineering Physics, Faculty of Industrial Technology, Institut Teknologi Sepuluh Nopember \\ Kampus Keputih ITS Sukolilo Surabaya 60111, INDONESIA \\ ${ }^{1}$ joe@ep.its.ac.id \\ 2ayulasryzaegmail.com
}

\begin{abstract}
This research focused on coal fly ash fabricated as CO adsorbent. Coal fly ash having grain size of 325 mesh was characterized by XRF, XRD and SEM-EDX. Physical activation was done at temperatures of $500^{\circ} \mathrm{C}$, $520^{\circ} \mathrm{C}, 540^{\circ} \mathrm{C}, 560^{\circ} \mathrm{C}, 580^{\circ} \mathrm{C}$ and $600^{\circ} \mathrm{C}$. Chemical activation was undertaken by mixing between fly ash and $\mathrm{NaOH}$ with mass ratio of $1: 1.2$ with subsequent heating at $750^{\circ} \mathrm{C}$ for $1 \mathrm{~h}$ and followed by washing the specimens until $\mathrm{pH}=7$. The samples were dried at $100^{\circ} \mathrm{C}$ for $1 \mathrm{~h}$. The major constituents of unactivated coal fly ash are $\mathrm{Fe}, \mathrm{Ca}, \mathrm{K}, \mathrm{Si}$ and $\mathrm{Al}$ in the form of quatz and anorthite. The chemical activation led to reduce the amount of quartz or increase the amount of anorthite. Physical activation does not affect the amount of minerals. Surface area of coal fly ash with physical activation at temperature $540^{\circ} \mathrm{C}$ and chemical activation is $32.444 \mathrm{~m}^{2} / \mathrm{g}$ (BET).
\end{abstract}

Keywords — fly ash; adsorbent; activation; characterization

Submitted: September 9, 2012

Accepted: October 23, 2012

\section{INTRODUCTION}

This document is a template. An electronic copy can be downloaded from the conference website. For questions on paper guidelines, please contact the conference publications committee as indicated on the conference website. Information about final paper submission is available from the conference website. Coal is one of alternative energy resources. In term of price coal is cheaper than natural oil. Indonesia has a lot of coal resources, and the utilization of coal in Indonesia increases every years. It attains $14,1 \%$ from total of other energy resources. It is expected that coal usage will increase until $34,6 \%$ at 2025[1]. Utilization of coal produces waste that can contaminate environment such as $\mathrm{CO}_{2}, \mathrm{NO}_{\mathrm{X}}, \mathrm{CO}, \mathrm{SO}_{2}$, hydrocarbon dan solid waste. The solid waste is in the form of ash, i.e fly ash and bottom ash. According to data of Ministry of Environment in 2006, fly ash production reaches 52,2 ton per day, whereas bottom ash waste production reaches 5,8 ton per day[1].

Coal fly ash is exhaust waste was usually released to air without control. Actually fly ash waste is a kind of hazardous waste. Generally, fly ash can be temporary saved at coal power plant and further thrown in landfill. Accumulation of this coal fly ash may raise environment al problem[2]. Coal fly ash can be used for raw material of cement and construction material[2]. Another utilization of coal is as adsorbent[3]. As adsorbent, fly ash has advantage in term of economical prices and good for gas and liquid waste management[4]. Physical and chemical activation is required to allow coal fly ash for being use as adsorbent. Physical activation is done by heating at high temperature, whereas chemical activation is done by mixing of fly ash and acid liquid or alkali.

\section{A. Materials}

\section{MATERIALS AND METHODS}

Coal fly ash is exhaust result of kiln I process in PT. Semen Gresik. It has grain size of 325 mesh. Coal fly ash have dark brown colour. This colour depend on type of coal, too. In this research the type of coal is lignite whose quality is the lowest among other type of coals.

\section{B. Methods}

Two activations were used in this research, namely physical and chemical activations. The physical activation was done by heating the sample at temperatures of $500^{\circ} \mathrm{C}, 520^{\circ} \mathrm{C}$, $540^{\circ} \mathrm{C}, 560^{\circ} \mathrm{C}, 580^{\circ} \mathrm{C}$, and $600^{\circ} \mathrm{C}$ for 1 hour. Chemical activation was done by mixing fly ash and $\mathrm{NaOH}$ with the mass fractions of fly ash and $\mathrm{NaOH}$ are $1: 1.2$. The mixtures were heated at temperature of $750^{\circ} \mathrm{C}$ for 1 hour followed by grinding process. Then, the samples were mixed with distilled water with $\mathrm{L} / \mathrm{S}$ of $1 / 5$ in a constant stirring of $400 \mathrm{rpm}$ for 30 minutes. Finally leaching was done until $\mathrm{pH}=7$, the samples were then subsequently dried at temperature of $100^{\circ} \mathrm{C}$ for 1 hour.

Raw material coal fly ash was characterized by X-Ray Fluorescence (Minipal4 PanAlytical), X-Ray Diffraction (Brücker AXS D8 Focus) Cu K- $\alpha$ with $\lambda=1,5418 \AA$, Scanning Electron Microscopy (SEM) Zeiss-EVO MA 10 equipped with Electron Diffraction-X (EDX) of Brücker, and BET analysis with Quantachrome Autosorb iQ.

\section{RESULTS AND DISCUSSION}

\section{A. Unactivated Coal Fly Ash Characterization}

Table 1 shows composition in unactivated fly ash. From Table 1 it is known that the highest contents in the fly ash are $\mathrm{Fe}, \mathrm{Ca}, \mathrm{K}, \mathrm{Si}$ and $\mathrm{Al}$, and the highest oxide are $\mathrm{Fe}_{2} \mathrm{O}_{3}, \mathrm{CaO}$, $\mathrm{SiO}_{2}, \mathrm{Al}_{2} \mathrm{O}_{3}$ and $\mathrm{K}_{2} \mathrm{O}$. The important substance for adsorbent are $\mathrm{Si}$ and $\mathrm{Al}$, while $\mathrm{Ca}$ is the substance that has to be remove. $\mathrm{Ca}$ can disturb the adsorption process because it may lead the reaction to become unstable.

Table 2 is mineral composition of unactivated coal fly ash from XRD analysis. XRD analysis shows that the most dominant minerals are amorphous structure and crystalline phase of quartz $\left(\mathrm{SiO}_{2}\right)$. Fly ash samples consist mainly amorphous aluminosilicate with a less number of iron-rich part. It is likely that the iron oxide bounds with aluminosilicate to form amorphous phase. While aluminum 
and silicon form either as sillimanite, quartz, or binds with $\mathrm{Ca}$ to form anorthite. Calcium was associated with oxygen, sulfur or with silicon or aluminum. The calcium-rich material is different in elemental composition from the amorphous alumino-silicate parts. It is clearly a non-silicate mineral possibly calcite, lime, gypsum or anhydrite[5].

TABLE I

XRF ANALYSIS OF UNACTIVATED COAL FLY ASH

\begin{tabular}{|c|c|c|c|c|}
\hline No. & Substance & $\begin{array}{c}\text { Concentrate } \\
(\%)\end{array}$ & Oxide & $\begin{array}{c}\text { Concentration } \\
(\%)\end{array}$ \\
\hline 1. & $\mathrm{Al}$ & 1,8 & $\mathrm{Al}_{2} \mathrm{O}_{3}$ & 2,9 \\
\hline 2. & $\mathrm{Si}$ & 9,3 & $\mathrm{SiO}_{2}$ & 14 \\
\hline 3. & $\mathrm{P}$ & 0,64 & $\mathrm{P}_{2} \mathrm{O}_{5}$ & 1,0 \\
\hline 4. & $\mathrm{~K}$ & 2,19 & $\mathrm{~K}_{2} \mathrm{O}$ & 1,84 \\
\hline 5. & $\mathrm{Ca}$ & 30,0 & $\mathrm{CaO}$ & 29,2 \\
\hline 6. & $\mathrm{Ti}$ & 1,79 & $\mathrm{TiO}_{2}$ & 2,9 \\
\hline 7. & $\mathrm{Mn}$ & 0,60 & $\mathrm{MnO}$ & 0,49 \\
\hline 8. & $\mathrm{Fe}$ & 51,23 & $\mathrm{Fe}_{2} \mathrm{O}_{3}$ & 46,51 \\
\hline 9. & $\mathrm{Ba}$ & 0,76 & $\mathrm{BaO}$ & 0,61 \\
\hline
\end{tabular}

TABLE III

XRD ANALYSIS OF UNACTIVATED COAL FLY ASH

\begin{tabular}{|c|l|c|c|}
\hline No. & \multicolumn{1}{|c|}{ Mineral } & Formula & Consentration (\%) \\
\hline 1. & Quartz & $\mathrm{SiO}_{2}$ & 21,1 \\
\hline 2. & Sillimanite & $\mathrm{Al}_{2} \mathrm{SiO}_{5}$ & 1,6 \\
\hline 3. & Anhydrite & $\mathrm{CaSO}_{4}$ & 0,7 \\
\hline 4. & Magnetite & $\mathrm{Fe}_{3} \mathrm{O}_{4}$ & 3,3 \\
\hline 5. & Anorthite & $\mathrm{Ca}_{3} \mathrm{SiO}_{5}$ & 1,7 \\
\hline 6. & Siderite & $\mathrm{FeCO}_{3}$ & 1,1 \\
\hline 7. & Arcanite & $\mathrm{K}_{2} \mathrm{SO}_{4}$ & 2,4 \\
\hline 8. & Periclase & $\mathrm{MgO}$ & 6,2 \\
\hline 9. & Hematite & $\mathrm{Fe}_{2} \mathrm{O}_{3}$ & 0,5 \\
\hline 10. & Maghemite & $\mathrm{Fe}_{2} \mathrm{O}_{3}$ & 3,9 \\
\hline 11. & Wuestite & $\mathrm{FeO}$ & 1,2 \\
\hline 12. & Amorphous & - & 54,9 \\
\hline
\end{tabular}

Figure 1 shows elemental mapping of unactivated fly ash. EDX analysis indicates that the big particle contains a lot of $\mathrm{Si}$ while $\mathrm{Fe}$ and $\mathrm{Al}$ distribute evenly in all particles. This evidence indicates intermixing of $\mathrm{Fe}$ and $\mathrm{Si}-\mathrm{Al}$ mineral phases while $\mathrm{Ca}$ may in form non-silicate minerals[5]. These results are supported with XRD data.

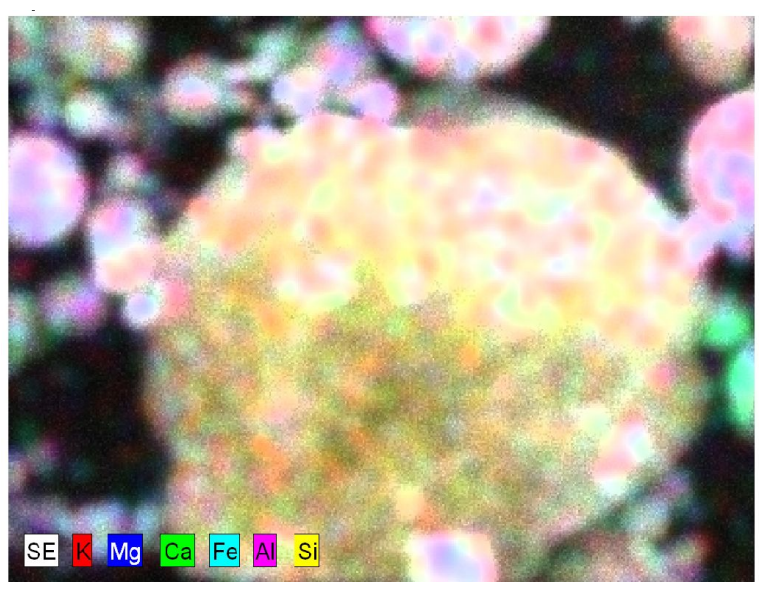

Fig. 1 Result SEM of unactivation coal fly ash

\section{B. Activation Coal Fly Ash Characterization}

From Table 3 and 4 one can observe that amorphous phase and quartz crystalline still dominate in fly ash after physical activation. There is little changes of mineral composition after physical activation. On the other hand, the chemical activation changed the amount of minerals in fly ash. For example, after chemical activation the amount of quartz decreases while the amount of anorthite increases. Figure 2 exemplifies the change in the amount of mineral of fly ash after physical and chemical activation. From figure 2 it is known that chemical activation plays an important in changing the amount of minerals, while the physical activation does not affect significantly.

TABLE III

XRD Quantitative Data of COAL Fly Ash With Physical ACtivation

\begin{tabular}{|c|c|c|c|c|c|c|c|c|}
\hline \multirow{2}{*}{$\begin{array}{c}\text { Crystal/ } \\
\text { Mineral }\end{array}$} & \multirow{2}{*}{ Formula } & \multirow{2}{*}{ Unit } & \multicolumn{6}{|c|}{ Physical Activation } \\
\cline { 4 - 9 } & & & $\mathbf{5 0 0}$ & $\mathbf{5 2 0}$ & $\mathbf{5 4 0}$ & $\mathbf{5 6 0}$ & $\mathbf{5 8 0}$ & $\mathbf{6 0 0}$ \\
\hline Quartz & $\mathrm{SiO}_{2}$ & $\%$ & 20,0 & 21,1 & 22,0 & 22,2 & 22,3 & 21,0 \\
\hline Sillimanite & $\mathrm{Al}_{2} \mathrm{SiO}_{5}$ & $\%$ & 4,2 & 2,8 & 3,2 & 2,5 & 3,1 & 2,8 \\
\hline Anhydrite & $\mathrm{CaSO}_{4}$ & $\%$ & 0,4 & 0,6 & 0,4 & 0,8 & 1,0 & 0,4 \\
\hline Magnetite & $\mathrm{Fe}_{3} \mathrm{O}_{4}$ & $\%$ & 2,9 & 3,2 & 3,6 & 3,9 & 3,2 & 3,5 \\
\hline Anorthite & $\mathrm{Ca}_{3} \mathrm{SiO}_{5}$ & $\%$ & 1,6 & 2,1 & 2,3 & 2,7 & 1,4 & 1,7 \\
\hline Siderite & $\mathrm{FeCO}_{3}$ & $\%$ & 1,1 & 0,9 & 1,4 & 1,1 & 1,2 & 1,3 \\
\hline Arcanite & $\mathrm{K}_{2} \mathrm{SO}_{4}$ & $\%$ & 2,7 & 2,8 & 2,4 & 2,1 & 2,8 & 3,1 \\
\hline Periclase & $\mathrm{MgO}$ & $\%$ & 6,7 & 6,3 & 5,9 & 7,4 & 6,6 & 6,4 \\
\hline Hematite & $\mathrm{Fe}_{2} \mathrm{O}_{3}$ & $\%$ & 0,5 & 0,6 & 0,5 & 0,6 & 0,6 & 0,6 \\
\hline Maghemite & $\mathrm{Fe}_{2} \mathrm{O}_{3}$ & $\%$ & 3,5 & 3,4 & 2,7 & 2,8 & 3,4 & 3,0 \\
\hline Wuestite & $\mathrm{FeO}$ & $\%$ & 0,5 & 1,2 & 0,8 & 0,6 & 0,9 & 0,9 \\
\hline Amorphous & - & $\%$ & 54,0 & 53,7 & 54,1 & 52,5 & 52,7 & 54,3 \\
\hline R_wp & - & $\%$ & 2,9 & 2,9 & 2,9 & 2,9 & 2,9 & 2,9 \\
\hline
\end{tabular}

TABLE IV

XRD QUANTITATIVE DATA of COAL Fly ASH WiTH CHEMical ACTIVATION

\begin{tabular}{|c|c|c|c|c|c|c|c|c|}
\hline \multirow{2}{*}{$\begin{array}{c}\text { Crystal/ } \\
\text { Mineral }\end{array}$} & \multirow{2}{*}{ Formula } & \multirow{2}{*}{ Unit } & \multicolumn{6}{|c|}{ Chemical Activation } \\
\cline { 4 - 9 } & & & $\mathbf{5 0 0}$ & $\mathbf{5 2 0}$ & $\mathbf{5 4 0}$ & $\mathbf{5 6 0}$ & $\mathbf{5 8 0}$ & $\mathbf{6 0 0}$ \\
\hline Quartz & $\mathrm{SiO}_{2}$ & $\%$ & 13,2 & 1,0 & 0,5 & 5,1 & 0,2 & 3,3 \\
\hline Sillimanite & $\mathrm{Al}_{2} \mathrm{SiO}_{5}$ & $\%$ & 0,0 & 2,6 & 4,0 & 2,5 & 4,3 & 8,4 \\
\hline Anhydrite & $\mathrm{CaSO}_{4}$ & $\%$ & 0,0 & 0,0 & 0,1 & 1,2 & 0,3 & 0,0 \\
\hline Magnetite & $\mathrm{Fe}_{3} \mathrm{O}_{4}$ & $\%$ & 3,1 & 3,4 & 0,1 & 0,0 & 4,3 & 3,5 \\
\hline Anorthite & $\mathrm{Ca}_{3} \mathrm{SiO}_{5}$ & $\%$ & 35,6 & 14,2 & 7,1 & 20,8 & 17,1 & 24,0 \\
\hline Siderite & $\mathrm{FeCO}_{3}$ & $\%$ & 1,3 & 0,0 & 0,0 & 0,2 & 0,2 & 0,2 \\
\hline Arcanite & $\mathrm{K}_{2} \mathrm{SO}_{4}$ & $\%$ & 14,1 & 18,0 & 16,9 & 18,6 & 15,3 & 14,8 \\
\hline Periclase & $\mathrm{MgO}$ & $\%$ & 11,9 & 15,3 & 22,5 & 12,2 & 9,9 & 6,5 \\
\hline Hematite & $\mathrm{Fe}_{2} \mathrm{O}_{3}$ & $\%$ & 0,2 & 0,0 & 1,4 & 0,1 & 0,1 & 0,1 \\
\hline Maghemite & $\mathrm{Fe}_{2} \mathrm{O}_{3}$ & $\%$ & 0,0 & 0,0 & 3,0 & 0,0 & 0,0 & 0,0 \\
\hline Wuestite & $\mathrm{FeO}$ & $\%$ & 1,0 & 2,8 & 6,2 & 2,7 & 4,6 & 2,0 \\
\hline Amorphous & - & $\%$ & 15,2 & 41,1 & 38,3 & 34,5 & 42,7 & 35,4 \\
\hline R_wp & - & $\%$ & 5,1 & 9,6 & 8,5 & 7,2 & 8,5 & 6,9 \\
\hline
\end{tabular}




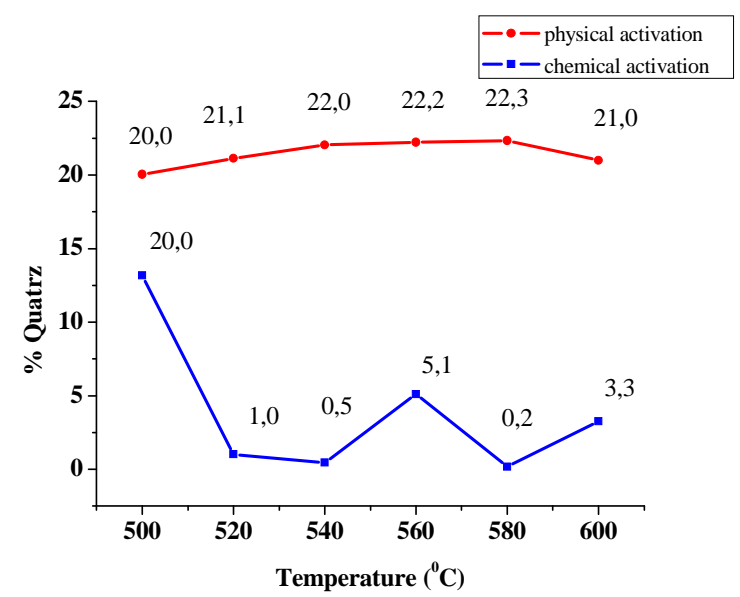

Fig. 2 Comparison of quartz contents after physical and chemical activation

There is also supported by BET analysis. The surface area of activated coal fly ash there is physical activation at temperature $540^{\circ} \mathrm{C}$ is $32.444 \mathrm{~m}^{2} / \mathrm{g}$ whereas unactivated coal fly ash is can not measured (BET). That is included mesopore material and supported by isoterm graphic on figure 3. Figure 3 shows that curve of activated fly ash is included type IV because between desorption line is not coincide with adsorption line and also indicated mesopore adsorbent[7].

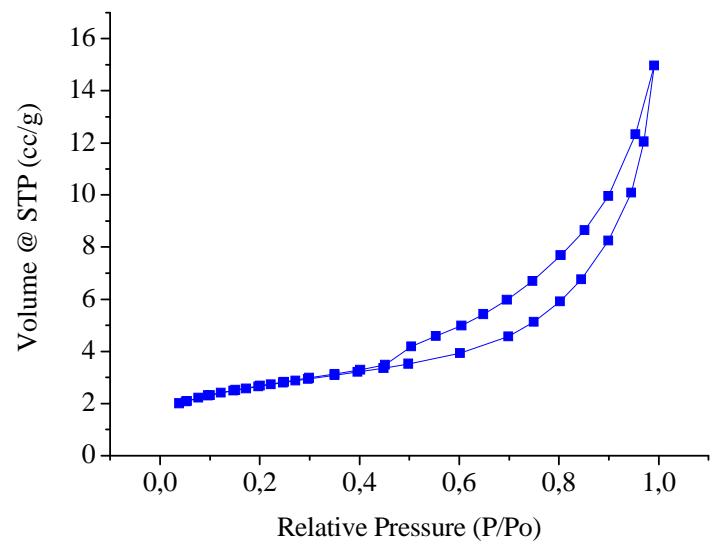

Fig. 3 Isoterm linear graphic of activated coal fly ash

Physical activation causes losing water content (intercrystalline water) in fly ash as indicated by thermogravimetry experiments [6]. Whereas chemical activation may active the unactivated substances, Else, activation process causes surface area changing of coal fly ash than unactivated coal fly ash, and finally aids the adsorption process.

\section{IV.CONCLUSIONS}

Unactivated coal fly ash consist mainly of $\mathrm{Fe}, \mathrm{ca}, \mathrm{K}, \mathrm{Si}$, and $\mathrm{Al}$, in the form of quartz and amorphous. The mineral contents were found to change after chemical activation e.g. quartz was reduced, anorthite was increased. Physical activation does not affect it. Surface area of coal fly ash is $32.444 \mathrm{~m}^{2} / \mathrm{g}$ (BET) that is known to change after activation proccess with phisical activation at temperature $540^{\circ} \mathrm{C}$ and also chemical activation.

\section{ACKNOWLEDGMENT}

The authors would like to thank to DITJEN DIKTI as organizer of Program Kreativitas Mahasiswa for funding this research, Mr. Heri Purnomo, ST from PT. Semen Gresik for his assistanship in XRD analysis, Ninit Martianingsih, S.Si who helps the SEM-EDX characterization, Nurul Faradillah Said, S.Si who helps the XRF characterization, and Endah Yuliyanti, S.Si who helps the BET characterization.

\section{REFERENCES}

[1] Setiaka, Juniawan, Ita Ulfin, Nurul Widiastuti, Adsorpsi Ion Logam $\mathrm{Cu}$ (ii) dalam Larutan pada Abu Dasar Batubara Menggunakan Metode Kolom. Prosiding Tugas Akhir. Jurusan Kimia, Institut Teknologi Sepuluh Nopember. Surabaya, 2011.

[2] Jumaeri,dkk, "Preparasi dan Karakterisasi Zeolit dari Abu Layang Batubara secara Alkali Hidrotermal," Reaktor, Vol. 11 No.1, Juni 2007, Hal. : 38-44, 2007

[3] Ahmaruzzaman M, "A review on the utilization of fly ash. Progress in Energy and Combustion Science," 36: 327-363, 2010.

[4] Mohan S, Gandhimathi R, "Removal of heavy metal ions from municipal solid waste leachate using coal fly ash as an adsorbent," Sience Direct. Journal of Hazardous Materials, 169: 351-359, 2009.

[5] Barbara G, Kutcko, Ann G. Kim, "Fly Ash Characterization by SEMEDS," Fuel, 85: 2537-2544, 2006.

[6] Lasryza, Ayu, "Pemanfaatan Fly Ash Batubara sebagai Adsorben Emisi Gas Buang CO pada Kendaraan Bermotor," Tugas Akhir Jurusan Teknik Fisika, Institut Teknologi Sepuluh Nopember. Surabaya, 2012.

[7] Anonim. (2012). Physisortion Methods and Techniques. [Online]. Available :

http://www.google.co.id/url?sa=t\&rct=j\&q=mesopore\&source=web\&c $\mathrm{d}=4 \& \mathrm{cad}=\mathrm{rja} \& \mathrm{ved}=0 \mathrm{CDQQFj} A D \& u r l=\mathrm{http}: / / \mathrm{www} \cdot$.sklc.dicp.ac.cn/yiq /Seminar\%2520JSD\%2520-

\%2520II.ppt\&ei=6K1_UP6LKJHwwRrQe3ooDIDQ\&usg=AFQjCNG hp5Ms2PcV9I1B2oB0viTxC1VPow 